\title{
Bicarbonate Attenuates Irinotecan-Induced Cytotoxicity through Regulation of Both Extracellular and Intracellular pHs in Intestine Cell Line
}

\author{
Teruo Miyazaki ${ }^{*}$, Tadashi Ikegami ${ }^{2}$, Yoshiaki Nagai $^{3}$, Erika Saitoh $^{3}$, Amy Nguyen $^{4}$, \\ Yasushi Matsuzaki ${ }^{2}$, Kunihiko Kobayashi ${ }^{3}$, Susan Ceryak ${ }^{5}$ \\ ${ }^{1}$ Joint Research Center, Tokyo Medical University Ibaraki Medical Center, Ami, Ibaraki, Japan; ${ }^{2}$ Department of Internal Medicine, \\ Division of Gastroenterology and Hepatology, Tokyo Medical University Ibaraki Medical Center, Ami, Ibaraki, Japan; ${ }^{3}$ Department \\ of Respiratory Medicine, Saitama International Medical Center, Saitama Medical University, Hidaka, Saitama, Japan; ${ }^{4}$ Department \\ of Biochemistry and Molecular Biology, The George Washington University, Washington DC, USA; ${ }^{5}$ Department of Pharmacology, \\ The George Washington University, Washington DC, USA. \\ Email: "teruom@tokyo-med.ac.jp
}

Received May $14^{\text {th }}, 2013$; revised June $12^{\text {th }}, 2013$; accepted June $19^{\text {th }}, 2013$

Copyright (C) 2013 Teruo Miyazaki et al. This is an open access article distributed under the Creative Commons Attribution License, which permits unrestricted use, distribution, and reproduction in any medium, provided the original work is properly cited.

\begin{abstract}
The anti-cancer therapy of irinotecan (CPT-11) is often limited due to severe late-onset diarrhea. Because the higher toxic form of CPT-11/its active metabolite (SN-38) is produced at acidification, the usefulness of oral sodium bicarbonate treatment against the CPT-11/SN-38-induced intestinal injuries and diarrhea has been confirmed. However, the roles of bicarbonate have been suggested to affect not only intestinal $p H$ environment but also intracellular $p H$ and CPT-11/SN-38 dynamics. The present study proposed to clarify the hypothesis in CPT-11/SN-38-exposed colon cell line in various $p H$ conditions adjusted by bicarbonate. HT29 cell pre-exposed to $\sim 1.0 \mu \mathrm{M} \mathrm{SN}-38$ lactone or carboxylate forms was incubated at different $p H$ adjusted by either bicarbonate or $\mathrm{HCl} / \mathrm{NaOH}$. The degrees of SN-38-induced cell injury depended on the higher proportion of the toxic form (lactone) of SN-38 rather than mere $p H$ condition of medium. Apoptosis and cell injury induced by $\mathrm{SN}-38$ were significantly inhibited by bicarbonate in a dose-dependent manner. Intercellular $\mathrm{pH}$ acidification induced by SN-38 was significantly prevented by $30 \mathrm{mM}$ bicarbonate. Cell cytotoxicity of $\mathrm{SN}-38$ depended on not only extracellular but also intracellular $p H$ that converts the SN-38 form, while the intracellular acidification was prevented by bicarbonate. The multiple regulations of bicarbonate on both exracellular and intracellular $p H$ would be essential mechanism against intestinal cell injury by CPT-11/SN-38.
\end{abstract}

Keywords: Bicarbonate; SN-38; CPT-11; pHi; Anti-Cancer Drug; Intestine

\section{Introduction}

Irinotecan hydrochloride (CPT-11; 7-ethyl-10-[4-(1-piperidino)-1-piperidino] carbonyloxy-camptothecin) is a water-soluble derivative of camptothecin, an alkaloid isolated from Camptotheca acuminata, and presents a wide spectrum of antitumor activity through the inhibition of DNA topoisomerase I [1]. This chemotherapeutic agent has been approved by the FDA for treatment of colorectal cancer in the United States, but has shown clinical responses for many other malignancies such as lung, gastric, pancreatic, cervical, and ovarian cancers as well as leukemia and lymphoma [2-6]. However, this agent has major limitation in the therapeutic use for the

${ }^{*}$ Corresponding author. patients with cancer due to severe side effect as the lethal delayed diarrhea $[7,8]$ including the marked intestinal injury and the presence of pseudomembranous jejunoileitis [9].

CPT-11 is hydrolyzed to active 7-ethyl-10-hydrocy-camptothecin (SN-38) by hepatic carboxylesterase [10], and $\mathrm{SN}-38$ has at least a 100 -fold more potent antitumor effect than CPT-11 [1]. The ability of both CPT-11 and SN-38 relies on $p H$. Both CPT-11 and SN-38 have a labile $\alpha$-hydroxy-3-lactone ring, which undergoes reversible hydrolysis at a rate that is mainly $p H$-dependent [11]. At acidic condition, the lactone ring of CPT-11/SN-38 closes, and this form is called as a lactone form. On the other hand, the lactone ring opens at physiological $p H$ and higher, and yields a carboxylate form. The carboxy- 
late form is a less potent inhibition of the topoisomerase I and has much weaker antitumor activity than its lactone counterpart. Therefore, one of the possible strategies for prevention from the CPT-11-induced side effects might be manipulating the $p H$-dependent interconversion. Indeed, we and others have previously confirmed the oral bicarbonate $\left(\mathrm{HCO}_{3}^{-}\right)$administration prior to and/or during CPT-11 treatment avoided acidifications in intestinal lumen and stool, and consequently, could decrease the incidence of side effects including delayed diarrhea, nausea, vomiting, myelotoxicity, and lymphocytopenia in the patients with lung cancer [12], advanced gastrointestinal cancer [13] or colorectal cancer [14], and the experimental animal model $[12,15]$. Therefore, it has been believed that oral $\mathrm{HCO}_{3}^{-}$treatment is effectiveness on the attenuation of the side effects in CPT-11 anticancer therapy through the keeping of intestinal alkalization.

Additionally, our previous studies also confirmed that there was significant difference in the initial uptake rate of CPT-11/SN-38 by isolated hamster intestinal cells between the respective lactone and carboxyrate forms $[9,15]$. The uptake rate of the lactone form that is passively transported was higher than the carboxyrate form that is actively absorbed. Therefore, the regulation of ambient $p H$ environment is also important factor for the intracellular uptake of CPT-11/SN-38.

Furthermore, intracellular $p H(p H i)$ is also associated with anti-cancer action of the agent, because it generally influences the cellular proliferation and death [16-19]. Because intracellular acidification is an early event in apoptosis and also essential in genomic DNA destruction [17], it has been also considered as one of the multiplier factors to emphasize the inhibitive action of SN-38 on the topoisomerase I [20]. In addition to the regulation of ambient $p H, \mathrm{HCO}_{3}^{-}$has been reported to act as a regulator of $\mathrm{pHi}$ in some cells through $\mathrm{Na}^{+}$-dependent $\mathrm{Cl}^{-} / \mathrm{HCO}_{3}^{-}$exchange, $\mathrm{Na}^{+}$-independent $\mathrm{Cl}^{-} / \mathrm{HCO}_{3}^{-}$exchange, and $\mathrm{Na}^{+}-\mathrm{HCO}_{3}^{-}$cotransport [21-23]. So, it is suggested that $\mathrm{HCO}_{3}^{-}$might have another potential protective action against $\mathrm{SN}-38$ through the regulation of the $p H i$.

While the oral $\mathrm{HCO}_{3}^{-}$treatment has demonstrated scientific and clinical benefits on CPT-11 treated anticancer therapy, there is few understanding of its action. In the present study, we purposed to clarify the implication of $\mathrm{HCO}_{3}^{-}$on $\mathrm{pH}$-dependent CPT-11/SN-38 toxicity in the human colon adenocarcinoma HT29 cell line under various culture $p H$ environments adjusted with/without $\mathrm{HCO}_{3}^{-}$.

\section{Materials and Methods}

\subsection{Materials}

SN-38 was supplied by Yakult Honsha Co., Ltd. (Tokyo,
Japan) and was $98 \%$ - 99\% pure as judged by gas-liquid chromatography. Nigericine was purchased from Sigma (St. Louis, MO). Snarf1-AM was from Calbiochem (San Diego, CA). Other chemicals were of the highest purity available. Dulbecco's Modified Eagle Medium (DMEM) and fetal bovine serum (FBS) were purchased from Gib$\mathrm{co}^{\circledR}$, Invitrogen Corporation (Carlsbad, CA). For the culture conditions, the HT29 cell line (ATCC ${ }^{\circledR}$, Manas- sas, VA) was maintained in DMEM supplemented with $10 \%$ heat-inactivated FBS, as previously described $[9,24,25]$. The HT29 model was selected since we have previ- ously reported a similar respective mechanism of uptake of SN-38 lactone and carboxylate to that reported in isolated intestinal cells [26]. Moreover, HT29 cells allow for long-term studies that are not possible using the isolated enterocyte model.

\subsection{Chemical (SN-38) Preparation}

SN-38 stock solution was prepared by dissolution with DMSO due to highly hydrophobicity. The SN-38 stock solution was incubated with $50 \mathrm{mM}$ PBS, $p H 3.0$ or 9.0, overnight at RT, as a 100-fold dilution, to obtain the lactone and carboxylate forms, respectively [27]. At this final concentration, DMSO was confirmed to have no effect on the initial uptake of the agent [26]. SN-38 at concentrations up to $5 \mu \mathrm{M}$ did not significantly change the $p H$ of the culture medium. The resultant solution was $98 \%$ lactone form at $p H 3.0$ and $97 \%$ carboxylate form at pH 9.0 (HPLC determination by Dr. K. Arimori and T. Hidaka, Dept. Pharmacy, Miyazaki Medical School, Miyazaki, Japan). For cell culture, SN-38 was diluted to final concentrations of 0.5 or $1.0 \mu \mathrm{M}$ in DMEM.

\subsection{Effect of Extracellular $p H$ on $\mathrm{SN}-38$-Induced Cytotoxicity}

HT29 cells seeded on a 96-well plate as density at $1 \times$ $10^{4}$ cells/well were cultured for $24 \mathrm{~h}$, and then exposed to either 0 or $0.5 \mu \mathrm{M} \mathrm{SN}-38$ lactone/carboxylate in DMEM for $2 \mathrm{~h}$ that the exposed period does not affect the interconversion of SN-38 $[10,28]$. The cells were then washed twice with PBS, and further incubated in DMEM without the $\mathrm{SN}-38$ at $p H 6.2$ or 7.2 set by $\mathrm{HCl} / \mathrm{NaOH}$ for $96 \mathrm{~h}$. Thereafter, cell viability was measured by the MTT assay, and expressed as a relative ratio to control $(0 \mu \mathrm{M}$ $\mathrm{SN}-38$ ) in each culture condition.

\subsection{The Effect of Bicarbonate-Adjusted $p H$ before and after $\mathrm{SN}-38$ Exposure}

HT29 cells seeded on a 24-well plate at a density of $5 \times$ $10^{4}$ cells/well were cultured in standard condition for 24 $\mathrm{h}$, and then, were incubated with DMEM containing 25 $\mathrm{mM}$ HEPES and increasing concentrations $(5,20,44$, $100 \mathrm{mM}$ ) of $\mathrm{HCO}_{3}^{-}$for $2 \mathrm{~h}$ prior to $\mathrm{SN}-38$ exposure. 
The $\mathrm{HCO}_{3}^{-}$concentrations resulted in the $\mathrm{pH}$ adjustment at 7.0, 7.2, 7.4, and 7.8, respectively. The osmolality was maintained constant among the different $\mathrm{HCO}_{3}^{-}$buffers. After the incubation with $\mathrm{HCO}_{3}^{-}$, cell was exposed to either 0.5 or $1.0 \mu \mathrm{M} \mathrm{SN}-38$ lactone for an additional $2 \mathrm{~h}$. Thereafter, cell was washed twice with PBS, and further incubated for an additional $96 \mathrm{~h}$ with the respective $\mathrm{HCO}_{3}^{-}$containing culture medium without SN-38. In parallel experiments, HT29 cell was cultured without $\mathrm{HCO}_{3}^{-}$prior to the SN-38 exposure, and were incubated with the different concentrations of $\mathrm{HCO}_{3}^{-}$during the additional $96 \mathrm{~h}$ exposure.

\subsection{Cell Viability in Various $p H$ Conditions with/without Bicarbonate}

HT29 cell cultured under standard condition containing DMEM with $44 \mathrm{mM} \mathrm{HCO}_{3}^{-}$, at $p H 7.4$, was exposed to either 0 or $1.0 \mu \mathrm{M} \mathrm{SN}-38$ lactone for $2 \mathrm{~h}$. Thereafter, the washed cell was further incubated for an additional $48 \mathrm{~h}$ with 5 -set points of $p H$ at $6.8,7.0,7.4,7.8$, or 8.2 in culture medium adjusted by either increasing concentrations of $\mathrm{HCO}_{3}^{-}\left[5,10,20,44,100 \mathrm{mM}\right.$, respectively; $\mathrm{HCO}_{3}^{-}$ $(+)]$ or $\mathrm{NaOH}$ with $5 \mathrm{mM} \mathrm{HCO}_{3}^{-}\left[\mathrm{HCO}_{3}^{-}(-)\right]$. During cell culture, acidification of medium is usually induced due to respiration of cells. Therefore, in the present experiment, the cell was cultured with different media in each condition to maintain $p H$ during culture. DMEM contained $2.5 \mathrm{mM} \cdot \mathrm{L}$-glutamate, $1 \mathrm{mM}$ sodium pyruvate, and $10 \%$ FBS, and each culture medium was constituted as shown in Table 1. The constitution of the medium was based on a previous study by Eagle et al. [29] and further modified in the present study. Cell proliferation after culture in these conditions was determined by the MTT assay.

For detection of apoptotic cells in the various $\mathrm{pH}$ co-

Table 1. Conditions of culture medium at different $\mathrm{pHs}$.

\begin{tabular}{cccccc}
\hline $\mathrm{HCO}_{3}^{-}(+)$ & $p H 6.8$ & $p H 7.0$ & $p H 7.4$ & $p H 7.8$ & $p H 8.2$ \\
\hline $\mathrm{NaHCO}_{3}(\mathrm{mM})$ & 5 & 10 & 20 & 44 & 100 \\
Hepes (mM) & 25 & 25 & 25 & 25 & 25 \\
\hline $\mathrm{HCO}_{3}^{-}(-)$ & $p H 6.8$ & $p H 7.0$ & $p H 7.4$ & $p H 7.8$ & $p H 8.2$ \\
\hline $\mathrm{NaHCO}_{3}(\mathrm{mM})$ & 5 & 5 & 5 & 5 & 5 \\
Trice (mM) & 10 & 0 & 0 & 0 & 0 \\
Hepes (mM) & 25 & 25 & 20 & 20 & 20 \\
$\mathrm{Tris}_{-}$base (mM) & 0 & 0 & 25 & 25 & 25 \\
$\mathrm{NaH}_{2} \mathrm{PO}_{4}(\mathrm{mM})$ & 10 & 10 & 0 & 0 & 0 \\
\hline
\end{tabular}

The cell was incubated in $5 \%$ and $0 \% \mathrm{CO}_{2}$, in $\mathrm{HCO}_{3}^{-}(+)$and $\mathrm{HCO}_{3}^{-}(-)$, respectively. nditions either with or without $\mathrm{HCO}_{3}^{-}$, following exposure to $\mathrm{SN}-38$ lactone, the cell was incubated with 3-set points of $p H$ at $6.8,7.0$, or 7.8 with increasing $\mathrm{HCO}_{3}^{-}$ concentrations $\left[\mathrm{HCO}_{3}^{-}(+)\right]$or without $\mathrm{HCO}_{3}^{-}\left[\mathrm{HCO}_{3}^{-}\right.$ $(-)]$ for an additional $48 \mathrm{~h}$.

\subsection{Cell Viability Assay}

Cell viability was analyzed as cell proliferation and apoptosis by the MTT assay [30] and flow cytometry, respectively. In the MTT assay, following incubation of the cell with the indicated concentration of the agents, the medium was removed and the cell was further incubated with $0.5 \mathrm{mg} / \mathrm{mL}$ MTT in medium for $4 \mathrm{~h}$ at $37^{\circ} \mathrm{C}$. The blue formazan compound was solubilized with methanol containing $0.01 \mathrm{~N} \mathrm{HCl}$. The absorbance was determined at $560 \mathrm{~nm}$, with $670 \mathrm{~nm}$ used as a reference in a spectrophotometer. In the flow cytometry, apoptotic HT29 cell was determined by annexin V and propidium iodide (PI) double staining using a commercially available kit (Annexin V-EGFP Apoptosis Detection Kit, BioVision, Inc., Mountain View, CA). Following the respective culture condition, the cell was harvested with trypsin and suspended with annexin V-enhanced green fluorescent protein (EGFP) and PI, and then analyzed by flow cytometry (FacSort, Becton Dickinson, San Jose, CA).

\subsection{Intracellular $p H$ Determination}

HT29 cell plated at $1 \times 10^{6}$ cells per well was incubated with and without $0.5 \mu \mathrm{M} \mathrm{SN}-38$ lactone for $2 \mathrm{~h}$ in culture medium containing increasing concentrations of $\mathrm{HCO}_{3}^{-}$ $(10-58 \mathrm{mM})$. After removal of $\mathrm{SN}-38$, the cell was maintained under the same culture conditions for an additional $4 \mathrm{~h}$ period before being loaded with $5 \mu \mathrm{M}$ Snarf-1 acetoxymethyl acetate for $20-40 \mathrm{~min}$ at $37^{\circ} \mathrm{C}$. The cell was then washed, and the respective cellular fluorescence level was determined with the ACAS 570 laser scanner cytometer (Meridian Instruments Inc., Okemos, MI). A pH standard curve $(6.8,7.2,7.4,7.6$, and 8.0) using high potassium concentration $(100 \mathrm{mM})$ was determined for each series of experiments using either PIPES for buffer $p H<7$ or HEPES for buffer $p H>$ 7 and $10 \mu \mathrm{M}$ nigericin. The cell membrane potassium ionophore nigericin causes the interior of the cells to equilibrate with the external $p H$ of the buffer. The cells were excited with a $514 \mathrm{~nm}$ argon laser beam $(5 \mathrm{~W}$, Innova $90 / 5$, Coherent) and the $587 \mathrm{~nm}$ and $640 \mathrm{~nm}$ emissions were simultaneously collected. The fluorescence intensity at each wavelength was detected using a photomultiplier tube. Images were acquired by scanning several fields of cells. Each image consisted of 3000 5000 discrete sample points. The ratio of the $640 / 587 \mathrm{~nm}$ emission data was used to determine the $\mathrm{pHi}$. On 
average, the data were collected from 12 - 20 successive scans.

\subsection{Statistical Analysis}

Statistically significant differences were assessed by applying the Student's unpaired $t$-test, paired $t$-test, or analysis of variance (ANOVA) where applicable with an $\alpha$ level of 0.05 . Control experiments, using only the vehicle for solubilizing the respective agent, were performed in parallel. The results were expressed as the mean $\pm \mathrm{SD}$ of the mean based on the number of studies. Each experiment was performed in duplicate or triplicate.

\section{Results}

\subsection{Effect of Extracellular $p H$ on SN-38-Induced Cellular Toxicity}

Table 2 shows the cell viability of HT29 cell after exposure to either the SN-38 lactone or carboxylate form in different two $\mathrm{pH}$ conditions at 7.4 or 6.2 adjusted by $\mathrm{NaOH} / \mathrm{HCl}$. At $p H 7.4$, cell viability was significantly decreased in the exposure to carboxylate form compared to that in the control, and was further and significantly decreased in the exposure to lactone form compared to that in other conditions. The significantly decreased cell viability in the lactone form rather than the carboxylate form was also observed at $p H$ 6.2. In addition, the viability in lactone form at $p H 6.2$ was significantly lower than carboxylate form at $p H$ 7.4. Compared between $p H 7.4$ and 6.2, the toxic level of SN-38 lactone was almost similar. These results are in agreement with the previous study reporting that cell cytotoxicity of SN-38 depended on the form, i.e., lactate or carboxylate forms rather than extracellular $p H$ [15].

\subsection{The Difference of Bicarbonate Treatment between before and after $\mathrm{SN}-38$ Exposure at Various $p H$ Conditions in the Cellular Toxicity}

Figure 1 presents the cell viability of HT29 cells cult-

Table 2. Effect of medium $p H$ on SN-38 toxicity.

\begin{tabular}{ccc}
\hline Agents & $p H$ Culture medium & Cell viability (\%) \\
\hline Control & 7.4 & 100 \\
SN-38 Lactone & 7.4 & $45.3 \pm 1.1^{* \dagger}$ \\
SN-38 Carbonate & 7.4 & $66.6 \pm 3.8^{*}$ \\
SN-38 Lactone & 6.2 & $44.8 \pm 1.6^{* \dagger}$ \\
Control & 6.2 & 100 \\
\hline
\end{tabular}

The values of cell viability are shown as the mean $\pm \mathrm{SD}(\%)$ relative to the respective control. ${ }^{*} p<0.05$; Significantly difference from the respective control, ${ }^{\dagger} p<0.05$; Significantly difference from SN-38 Carbonate.
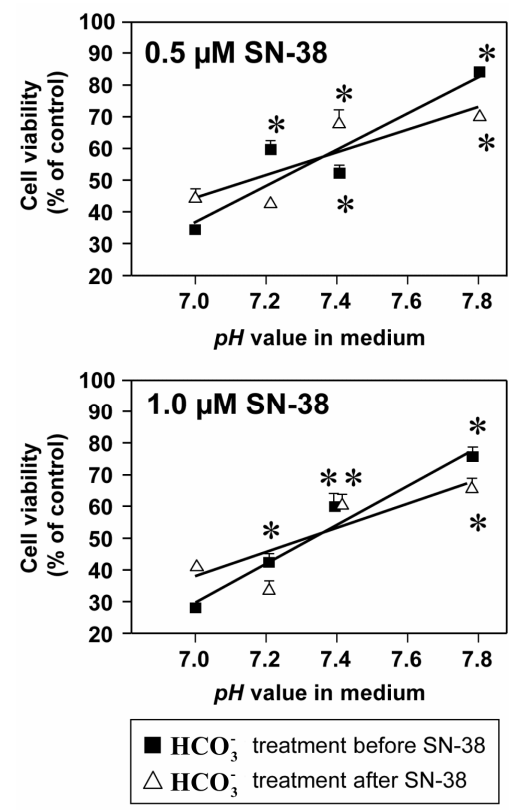

Figure 1. Effect of bicarbonate on $\mathrm{SN}-38$-induced toxicity in HT29 cell. The cell was incubated with $\mathrm{SN}-38(0.5$ or $1.0 \mu \mathrm{M})$ for $2 \mathrm{~h}$ and increasing concentrations of bicarbonate $\left(\mathrm{HCO}_{3}^{-} ; 5,20,44\right.$, and $100 \mathrm{mM}$ ) corresponding to $\mathrm{pH} 7.0$, 7.2, 7.4, and 7.8, respectively, either for $2 \mathrm{~h}$ before (Closed squares) or after (Opened triangles) the $\mathrm{SN}-38$ exposure. The cell in both conditions was further cultured in the medium with these increasing concentrations of $\mathrm{HCO}_{3}^{-}$for additional $96 \mathrm{~h}$. Cell viability was determined by the MTT assay. Data are shown as the mean \pm SD of the percent of the respective control $(0 \mu \mathrm{M}$ SN-38 treatment). "Significantly different from the respective control determined in the presence of $5 \mathrm{mM}$ bicarbonate, $p<0.05$.

ured with increasing concentrations of $\mathrm{HCO}_{3}^{-}$before to or after SN-38 exposures $(0.5$ or $1.0 \mu \mathrm{M})$ for $2 \mathrm{~h}$. With $\mathrm{HCO}_{3}^{-}$treatment before $0.5 \mu \mathrm{M} \mathrm{SN}-38$ exposure, cell viability was significantly higher at $p H 7.2,7.4$, and 7.8 than at $p H 7.0$, and at $p H 7.8$ was the highest. Similarly, with $\mathrm{HCO}_{3}^{-}$treatment after $0.5 \mu \mathrm{M} \mathrm{SN}-38$, cell viability at $p H 7.4$ and 7.8 was significantly higher compared to that at $p H$ 7.0. Moreover, these characteristic patterns of viability seen in the $0.5 \mu \mathrm{M} \mathrm{SN}-38$ were also observed in the exposure to $1.0 \mu \mathrm{M} \mathrm{SN}-38$. There was no difference in $\mathrm{SN}-38$-induced toxicity in the respective $\mathrm{pH}$ condition between $\mathrm{HCO}_{3}^{-}$treatment before and after SN-38 exposures. The results indicate that $\mathrm{HCO}_{3}^{-}$does not affect the conversion of SN-38 in the relatively short $2 \mathrm{~h}$ exposure period that is similar to small intestine transit time.

In addition, HT29 cell was incubated with the different $\mathrm{HCO}_{3}^{-}$buffers for $4 \mathrm{~h}$ before and during $1.0 \mu \mathrm{M} \mathrm{SN}-38$ lactone exposure. The cell was then washed and incubated in fresh DMEM containing $44 \mathrm{mM} \mathrm{HCO}_{3}^{-}(p H$ 
7.4) for $96 \mathrm{~h}$. Because the result showed that SN-38-induced toxicity was around $50 \%$ under all the different conditions (data not shown), it implied that $\mathrm{HCO}_{3}^{-}$ could not modify the influence of SN-38 on cell viability.

\subsection{Effect of Bicarbonate-Adjusted $p H$ on Cell Viability}

Figure 2(a) shows the viability of HT29 cell treated with various $p H$ conditions $(6.8-8.2)$ adjusted by increasing concentrations of $\mathrm{HCO}_{3}^{-}$or $\mathrm{NaOH}$ for $48 \mathrm{~h}$ following a $2 \mathrm{~h} \mathrm{SN}-38$ exposure. In the $\mathrm{HCO}_{3}^{-}$treatment, the cell viability was significantly enhanced at $p H 7.4,7.8$, and 8.2 compared to that at $p H 6.8$. On the other hand, there was no difference in the viability of HT29 cell treated without $\mathrm{HCO}_{3}^{-}$among these $p H$ conditions. In these experiments, the $p H$ in the medium was almost perfectly maintained even after cell culture, and there was no difference in $p H$ after culture between control and SN-38 exposure in both experiments (Figure 2(b)).

Figure 3 shows the flow cytometry image (Figure 3(a)) and the percentage of apoptotic cells analyzed by flow cytometry (Figure 3(b)) in the different $p H$ conditions $\left(48 \mathrm{~h}\right.$ ) with or without $\mathrm{HCO}_{3}^{-}$following a $2 \mathrm{~h} \mathrm{ex-}$ posure to $1 \mu \mathrm{M} \mathrm{SN}-38$ lactone. In the control, the per centage of necrotic cells (double positive for annexin V-EGFP and PI) was higher at $p H 6.8$ with $5 \mathrm{mM}$ $\mathrm{HCO}_{3}^{-}$than at $p H 7.8$ with $44 \mathrm{mM} \mathrm{HCO}_{3}^{-}$(Figure 3(a)). The necrosis at $p H 6.8$ was further aggravated by exposure to SN-38. Furthermore, the percentage of apoptotic cells (annexin V-EGFP positive) was increased. In the $\mathrm{SN}-38$-exposed cells, the numbers of apoptotic and necrotic cells were lower at $p H 7.8$ than at $p H 6.8$. In the control cells, apoptotic cells were around $10 \%$ in all 3-set $p H$ conditions despite of $\mathrm{HCO}_{3}^{-}$treatment (Figure 3(b)). In case of SN-38-exposed cells, the apoptosis was enhanced by around $40 \%$ in all three $p H$ conditions of $\mathrm{HCO}_{3}^{-}(-)$. On the other hand, the SN-38-induced apoptosis was significantly inhibited at $p H 7.0$ and 7.8 with increasing $\mathrm{HCO}_{3}^{-}$concentrations compared to that at $p H$ 6.8. These results show that higher $p H$ conditions adjusted by $\mathrm{HCO}_{3}^{-}$could inhibit the cellular toxicity induced by $\mathrm{SN}-38$.

\subsection{Effect of Bicarbonate on pHi Alternation Induced by $\mathrm{SN}-38$}

The level of $\mathrm{pHi}$ was determined in the presence of either 10 or $30 \mathrm{mM} \mathrm{HCO}-$ following $\mathrm{SN}-38$ (Figure 4). In the $10 \mathrm{mM} \mathrm{HCO}_{3}^{-}$, pHi level in $\mathrm{SN}-38$-exposed cells was significantly decreased compared to that in the control. On the other hand, there was no significant difference in the $\mathrm{pHi}$ between the control and $\mathrm{SN}-38$-exposed cells in the presence of $30 \mathrm{mM} \mathrm{HCO}_{3}^{-}$. Similar results
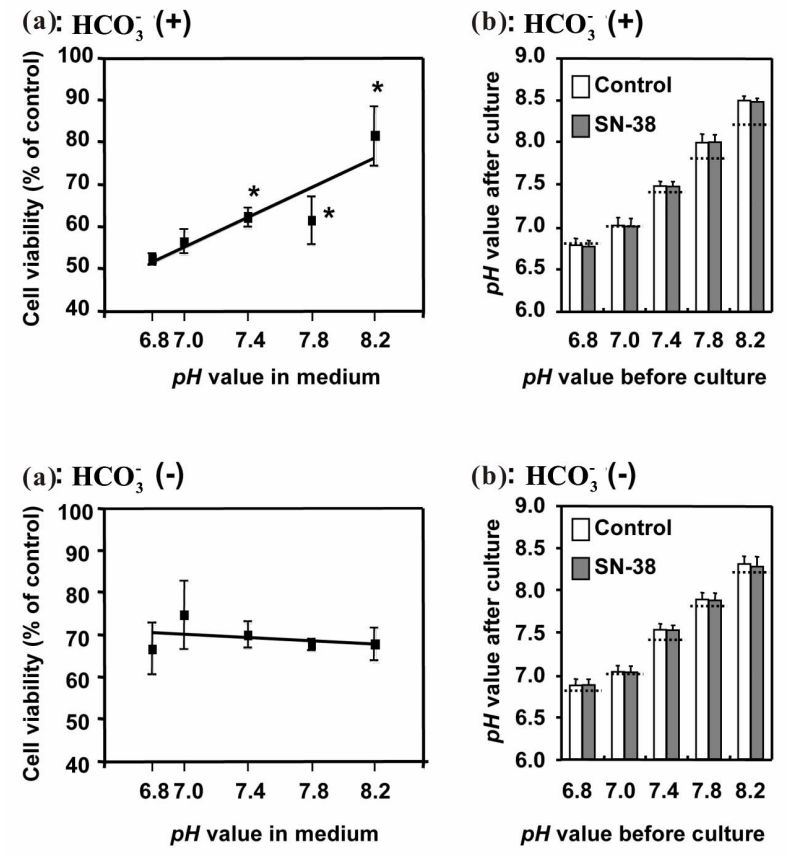

Figure 2. Effect of bicarbonate-adjusted $p H$ on cell viability (a) and $\mathrm{pH}$ values in medium after cell culture (b). The cells incubated with/without $1.0 \mu \mathrm{M} \mathrm{SN}-38$ for $2 \mathrm{~h}$ were cultured with $\mathrm{pH}$ set media at 5 points $(6.8,7.0,7.4,7.8,8.2)$ adjusted by either different concentrations $(5,10,20,44,100 \mathrm{mM}$, respectively) of bicarbonate $\left[\mathrm{HCO}_{3}^{-}(+)\right]$or $\mathrm{NaOH}\left[\mathrm{HCO}_{3}^{-}\right.$ (-)]. (a) Cell viability evaluated by MTT assay was shown as the percent of the respective control $(0 \mu \mathrm{M} \mathrm{SN}-38) .{ }^{*} p<0.05$; Significantly different from $p H$ 6.8; (b) The 5-set points of culture media adjusted by either increasing concentrations of bicarbonate $\left[\mathrm{HCO}_{3}^{-}(+)\right]$or $\mathrm{NaOH}\left[\mathrm{HCO}_{3}^{-}(-)\right]$were measured after the cell culture. The dotted lines on each column show the set- $p H$ values before the cell culture. The $p H$ in each culture medium was measured using a standard pH meter in triplicate from three samples immediately after culture.

were obtained with a higher concentration of $\mathrm{HCO}_{3}^{-}$ $\left(58 \mathrm{mM}\right.$ ) as those obtained with $30 \mathrm{mM} \mathrm{HCO}_{3}^{-}$(no data shown). The results indicate that higher concentrations of $\mathrm{HCO}_{3}^{-}$could prevent intracellular acidification caused by $\mathrm{SN}-38$.

\section{Discussion}

Diarrhea is one of the lethal major side effects in the cancer patients receiving CPT-11 [7,31]. We and others have previously demonstrated that intestinal alkalization by $\mathrm{HCO}_{3}^{-}$could reduce CPT-11/SN-38-induced cell injuries and diarrhea in both in vitro and in vivo studies $[12,13,15]$. These studies were based on the role of $\mathrm{HCO}_{3}^{-}$on intestinal $\mathrm{pH}$ regulation because of the $\mathrm{pH}$ dependent cytotoxicity of CPT-11/SN-38 [1,9,10,12,14, $15,28,32,33]$. In addition to the regulation of $p H$ in the 
(a)
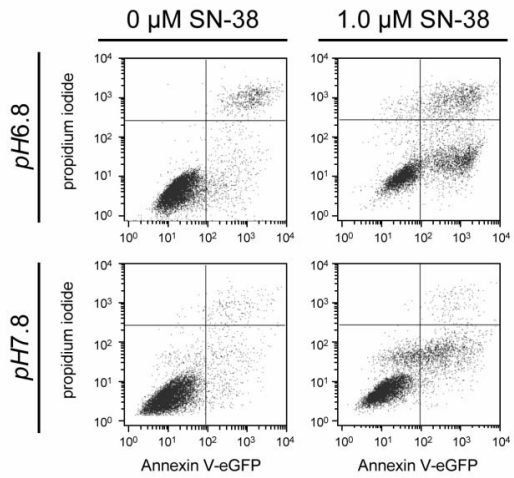

(b)

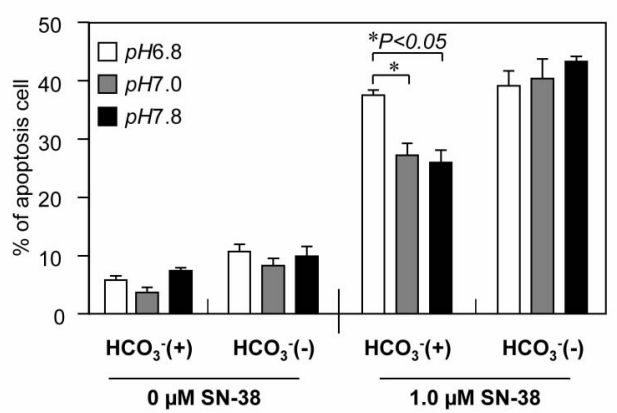

Figure 3. Effect of bicarbonate-adjusted $\mathrm{pH}$ on apoptosis. The cell following exposure to $\mathrm{SN}-38$ was incubated for an additional $48 \mathrm{~h}$ in 3 -set $p H$ conditions $(6.8,7.0$, or 7.8) either in $\mathrm{HCO}_{3}^{-}(+)$or $\mathrm{HCO}_{3}^{-}(-)$medium. See the legend of Figure 2 for the bicarbonate concentrations that were used to set the $p H$ in the medium. Figure 3(a) shows the images of flow cytometry in the cells exposed to either 0 or $1.0 \mu \mathrm{M}$ $\mathrm{SN}-38$ lactone in $\mathrm{HCO}_{3}^{-}(+)$conditions set at $\mathrm{pH} 6.8$ or 7.8 .

The apoptotic cells were expressed as the percentage of cells stained with annexin V-EGFP positive and PI negative to the total numbers of cells, and shown as the mean \pm SD in Figure 3(b).

intestinal lumen, we suggested that $\mathrm{HCO}_{3}^{-}$might play other roles on cytoprotection against $\mathrm{CPT}-11 / \mathrm{SN}-38$ through influence on $\mathrm{pHi}$ environment. Palissot et al. have reported that the CPT-11/SN-38-induced apoptosis was less in the multidrug-resistant HL60-Vinc leukemic cells that could keep $\mathrm{pHi}$ higher, while apoptosis was much in drug-sensitive HL60 cell which intercellular acidification was induced following CPT-11/SN-38 treatment [34]. Therefore, the regulation of $\mathrm{pHi}$ level would be associated with the sensitive to CPT-11/SN-38 [18].

Accordingly, we designed a series of experiments in the large intestine cell line to test the hypothesis that the $\mathrm{HCO}_{3}^{-}$might influence on not only extracellular $\mathrm{pH}$ but also $\mathrm{pHi}$ environments, and consequently, disturb the intracellular conversion of SN-38 from the less toxic carboxylate form to the more toxic lactone form $[9,35]$. In the result, the cytotoxicity induced by SN-38 lactone

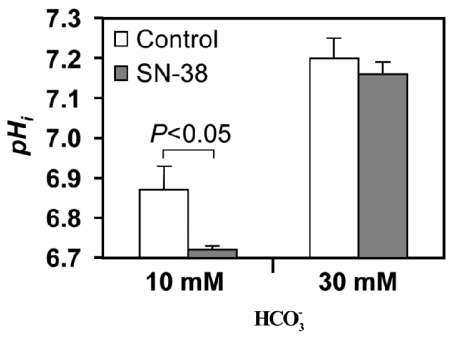

Figure 4. Effect of bicarbonate on $\mathrm{SN}-38$-induced change in intracellular $\mathrm{pH}$. Changes in $\mathrm{pHi}$ was assessed following incubation of the HT29 cell in the presence and absence of $0.5 \mu \mathrm{M} \mathrm{SN}-38$ for $2 \mathrm{~h}$ and in a culture medium containing either 10 or $30 \mathrm{mM}$ bicarbonate. The $\mathrm{pHi}$ was determined 4 $h$ after removal of $\mathrm{SN}-38$.

form was attenuated in a dose-dependent matter of $\mathrm{HCO}_{3}^{-}$, but not by the respective $\mathrm{pH}$ condition merely adjusted by $\mathrm{NaOH} / \mathrm{HCl}$ with low concentration of $\mathrm{HCO}_{3}^{-}$. Although the $\mathrm{HCO}_{3}^{-}$itself changes medium $p H$, the result implies that the cell damages induced by $\mathrm{SN}-38$ would depend on not only ambient $p H$ environment because the exposed time to $\mathrm{SN}-38$ was only 2 hours that is too short to cause interconversion of SN-38 forms, and therefore, $\mathrm{HCO}_{3}^{-}$might play other roles on the protection against $\mathrm{SN}-38$. One of the possibilities is that $\mathrm{HCO}_{3}^{-}$would be uptaked into cells, and then, would affect the $\mathrm{pHi}$. Indeed, the present study confirmed that a higher concentration of $\mathrm{HCO}_{3}^{-}(30 \mathrm{mM})$ could inhibit SN-38-induced intracellular acidification (Figure 4).

Furthermore, cellular acidification becomes a trigger in the early phase of apoptosis because of activation of endonucleases, and thus, regulation of $\mathrm{pHi}$ is critically important for tumor development [21]. The present study showed that the SN-38 itself has the action to cause intercellular acidification in the intestinal cell. Besides the inhibition of DNA topoisomerase I, it means that intercellular SN-38 also behaves as a trigger of apoptosis. Therefore, the regulation of $\mathrm{pHi}$ should be further important for attenuation of the side effects on CPT-11/ SN-38 therapy. In addition to the effect of $\mathrm{HCO}_{3}^{-}$on $\mathrm{SN}-38$-induced intercellular acidification, Flow Cytometry assay showed that apoptosis following SN-38 exposure was significantly decreased by increasing concentrations of $\mathrm{HCO}_{3}^{-}$, but not in the respective $\mathrm{pH}$ level adjusted by $\mathrm{NaOH} / \mathrm{HCl}$. These findings implied that the regulation of $p H i$ by $\mathrm{HCO}_{3}^{-}$is effectiveness on the prevention of SN-38 induced apoptosis in intestinal cells.

In addition to the interconversion of CPT-11/SN-38, $p H$ environment is also associated with other characteristics of the agents. Gabr et al. have reported in L1210 leukemia cells that the uptake of radiolabeled CPT-11 was more rapidly at $p H 6.2$ than at physiological $p H$ 7.4, and the intercellular retention was predominant at $p H 6.2$ 
[36]. Similarly, we have previously reported that the uptake of SN-38 into HT29 cells was significantly increased at ambient lower $p H$ [9]. In this point, $\mathrm{HCO}_{3}^{-}$is indirectly contributed on the cellular uptake of $\mathrm{SN}-38$ by regulation of ambient $p H$ level.

In conclusion, the present study confirmed that $\mathrm{HCO}_{3}^{-}$could keep alkalization/neutralization in not only extracellular but also intracellular $p H$ environments, and consequently, cytotoxicity in large intestine cells would be attenuated through the reductions of interconversion to more toxic form and cellular uptake of SN-38. These results would certify the multiple roles of $\mathrm{HCO}_{3}^{-}$on the attenuation of side effects; cell injuries and diarrhea, in CPT-11/SN-38 antitumor therapy.

\section{Acknowledgements}

We are grateful for the expert advises from the late Dr. Bernard Bouscarel who was associate professor in the Department of Biochemistry and Molecular Biology of the George Washington University, Washington DC, USA. This study was supported in part by the National Institutes of Health Grant; DK-56108, Daiichi Pharmaceutical Co. Ltd., (Tokyo, Japan), Yakult Honsha Co. Ltd., (Tokyo, Japan), Mitsubishi Welpharma Co., Ltd. (Osaka, Japan), and the Elaine H. Snyder Cancer Research Award. This work was presented, in part, at the annual meetings of the American Gastroenterology Association in May 2002 and of the American Association for Cancer Research in April 2010. We thank Mr. Amit Kashyap and Miss Ivy Akid for their technical assistance.

\section{REFERENCES}

[1] Y. Kawato, M. Aonuma, Y. Hirota, H. Kuga and K. Sato, "Intracellular Roles of SN-38, a Metabolite of the Camptothecin Derivative CPT-11, in the Antitumor Effect of CPT-11," Cancer Research, Vol. 51, No. 16, 1991, pp. 4187-4191.

[2] S. Kudoh, Y. Fujiwara, Y. Takada, H. Yamamoto, A. Kinoshita, Y. Ariyoshi, K. Furuse, M. Fukuoka and West Japan Lung Cancer Group, "Phase II Study of Irinotecan Combined with Cisplatin in Patients with Previously Untreated Small-Cell Lung Cancer," Journal of Clinical Oncology, Vol. 16, No. 3, 1998, pp. 1068-1074.

[3] W. P. Irvin, F. V. Price, H. Bailey, M. Gelder, R. Rosenbluth, H. J. Durivage and R. K. Potkul, "A Phase II Study of Irinotecan (CPT-11) in Patients with Advanced Squamous Cell Carcinoma of the Cervix," Cancer, Vol. 82, No. 2, 1998, pp. 328-333.

doi:10.1002/(SICI)1097-0142(19980115)82:2<334::AIDCNCR13>3.0.CO;2-\#

[4] C. F. Verschraegen, T. Levy, A. P. Kudelka, E. Llerena, K. Ende, R. S. Freedman, C. L. Edwards, M. Hord, M. Steger, A. L. Kaplan, D. Kieback, A. Fishman and J. J. Kavanagh, "Phase II Study of Irinotecan in Prior Chemo-
therapy-Treated Squamous Cell Carcinoma of the Cervix," Journal of Clinical Oncology, Vol. 15, No. 2, 1997, pp. 625-631.

[5] Y. Shimizu, S. Umezawa and K. Hasumi, "Successful Treatment of Clear Cell Adenocarcinoma of the Ovary (OCCA) with a Combination of CPT-11 and Mitomycin C," Gan to Kagaku Ryoho, Vol. 23, No. 5, 1996, pp. $587-$ 593.

[6] H. C. Pitot, D. B. Wender, M. J. O'Connell, G. Schroeder, R. M. Goldberg, J. Rubin, J. A. Mailliard, J. A. Knost, C. Ghosh, R. J. Kirschling, R. Levitt and H. E. Windschitl, "Phase II Trial of Irinotecan in Patients with Metastatic Colorectal Carcinoma," Journal of Clinical Oncology, Vol. 15, No. 8, 1997, pp. 2910-2919.

[7] D. J. Sargent, D. Niedzwiecki, M. J. O’Connell and R. L. Schilsky, "Recommendation for Caution with Irinotecan, Fluorouracil, and Leucovorin for Colorectal Cancer," The New England Journal of Medicine, Vol. 345, No. 2, 2001, pp. 144-145. doi:10.1056/NEJM200107123450213

[8] L. Saltz, "Irinotecan-Based Combinations for the Adjuvant Treatment of Stage III Colon Cancer," Oncology (Williston Park), Vol. 14, No. 12, 2000, pp. 47-50.

[9] K. Kobayashi, B. Bouscarel, Y. Matsuzaki, S. Ceryak, S. Kudoh and H. Fromm, "pH-Dependent Uptake of Irinotecan and Its Active Metabolite, SN-38, by Intestinal Cells," International Journal of Cancer, Vol. 83, No. 4, 1999, pp. 491-496. doi:10.1002/(SICI)1097-0215(19991112)83:4<491::AIDIJC10>3.3.CO;2-D

[10] L. P. Rivory, M. R. Bowles, J. Robert and S. M. Pond, "Conversion of Irinotecan (CPT-11) to Its Active Metabolite, 7-Ethyl-10-hydroxycamptothecin (SN-38), by Human Liver Carboxylesterase," Biochemical Pharmacology, Vol. 52, No. 7, 1996, pp. 1103-1111. doi:10.1016/0006-2952(96)00457-1

[11] J. Fassberg and V. J. Stella, "A Kinetic and Mechanistic Study of the Hydrolysis of Camptothecin and Some Analogues," Journal of Pharmaceutical Sciences, Vol. 81, No. 7, 1992, pp. 676-684. doi:10.1002/jps.2600810718

[12] Y. Takeda, K. Kobayashi, Y. Akiyama, T. Soma, S. Handa, S. Kudoh and K. Kudo, "Prevention of Irinotecan (CPT-11)-Induced Diarrhea by Oral Alkalization Combined with Control of Defecation in Cancer Patients," International Journal of Cancer, Vol. 92, No. 2, 2001, pp. 269-275.

doi:10.1002/1097-0215(200102)9999:9999<::AID-IJC11 79>3.0.CO;2-3

[13] V. Valenti Moreno, J. Brunet Vidal, H. Manzano Alemany, A. Salud Salvia, M. Llobera Serentill, I. Cabezas Montero, S. Servitja Tormo, E. Sopena Bert and J. Guma Padro, "Prevention of Irinotecan Associated Diarrhea by Intestinal Alkalization. A Pilot Study in Gastrointestinal Cancer Patients," Clinical and Translational Oncology, Vol. 8, No. 3, 2006, pp. 208-212. doi:10.1007/s12094-006-0012-1

[14] T. Tamura, K. Yasutake, H. Nishisaki, T. Nakashima, K. Horita, S. Hirohata, A. Ishii, K. Hamano, N. Aoyama, D. Shirasaka, T. Kamigaki and M. Kasuga, "Prevention of 
Irinotecan-Induced Diarrhea by Oral Sodium Bicarbonate and Influence on Pharmacokinetics," Oncology, Vol. 67, No. 5-6, 2004, pp. 327-337. doi:10.1159/000082915

[15] T. Ikegami, L. Ha, K. Arimori, P. Latham, K. Kobayashi, S. Ceryak, Y. Matsuzaki and B. Bouscarel, "Intestinal Alkalization as a Possible Preventive Mechanism in Irinotecan (CPT-11)-Induced Diarrhea," Cancer Research, Vol. 62, No. 1, 2002, pp. 179-187.

[16] R. Belhoussine, H. Morjani, R. Gillet, V. Palissot and M. Manfait, "Two Distinct Modes of Oncoprotein Expression during Apoptosis Resistance in Vincristine and Daunorubicin Multidrug-Resistant HL60 Cells," Advances in Experimental Medicine and Biology, Vol. 457, 1999, pp. 365-381. doi:10.1007/978-1-4615-4811-9 39

[17] R. A. Gottlieb, J. Nordberg, E. Skowronski and B. M. Babior, "Apoptosis Induced in Jurkat Cells by Several Agents Is Preceded by Intracellular Acidification," Proceedings of the National Academy of Sciences of the United States of America, Vol. 93, No. 2, 1996, pp. 654-658. doi:10.1073/pnas.93.2.654

[18] A. K. Larsen, A. E. Escargueil and A. Skladanowski, "Resistance Mechanisms Associated with Altered Intracellular Distribution of Anticancer Agents," Pharmacology \& Therapeutics, Vol. 85, No. 3, 2000, pp. 217-229. doi:10.1016/S0163-7258(99)00073-X

[19] K. H. Sit, B. H. Bay and K. P. Wong, "Effect of Genistein, a Tyrosine-Specific Protein Kinase Inhibitor, on Cell Rounding by $\mathrm{Ph}$ Upshifting," In Vitro Cellular \& Developmental Biology-Animal, Vol. 29A, No. 5, 1993, pp. 395-402. doi:10.1007/BF02633988

[20] J. F. Goossens, J. P. Henichart, L. Dassonneville, M. Facompre and C. Bailly, "Relation between Intracellular Acidification and Camptothecin-Induced Apoptosis in Leukemia Cells," European Journal of Pharmaceutical Sciences, Vol. 10, No. 2, 2000, pp. 125-131. doi:10.1016/S0928-0987(99)00091-3

[21] H. Izumi, T. Torigoe, H. Ishiguchi, H. Uramoto, Y. Yoshida, M. Tanabe, T. Ise, T. Murakami, T. Yoshida, M. Nomoto and K. Kohno, "Cellular pH Regulators: Potentially Promising Molecular Targets for Cancer Chemotherapy," Cancer Treatment Reviews, Vol. 29, No. 6, 2003, pp. 541-549. doi:10.1016/S0305-7372(03)00106-3

[22] R. D. Vaughan-Jones and K. W. Spitzer, "Role of Bicarbonate in the Regulation of Intracellular $\mathrm{pH}$ in the Mammalian Ventricular Myocyte," Biochemistry and Cell Biology, Vol. 80, No. 5, 2002, pp. 579-596. doi:10.1139/o02-157

[23] D. Gleeson, N. D. Smith and J. L. Boyer, "BicarbonateDependent and -Independent Intracellular pH Regulatory Mechanisms in Rat Hepatocytes. Evidence for $\mathrm{Na}^{+}-$ $\mathrm{HCO}_{3}^{-}$Cotransport," Journal of Clinical Investigation, Vol. 84, No. 1, 1989, pp. 312-321. doi:10.1172/JCI114156

[24] B. Bouscarel, C. Cortinovis, C. Carpene, J. C. Murat and H. Paris, "Alpha 2-Adrenoceptors in the HT 29 Human Colon Adenocarcinoma Cell Line: Characterization with $[3 \mathrm{H}]$ clonidine; Effects on Cyclic AMP Accumulation," European Journal of Pharmacology, Vol. 107, No. 2,
1985, pp. 223-231. doi:10.1016/0014-2999(85)90062-7

[25] H. Paris, B. Bouscarel, C. Cortinovis and J. C. Murat, "Growth-Related Variation of Alpha 2-Adrenergic Receptivity in the HT 29 Adenocarcinoma Cell-Line from Human Colon," FEBS Letters, Vol. 184, No. 1, 1985, pp. 82-86. doi:10.1016/0014-5793(85)80658-X

[26] K. Kobayashi, B. Bouscarel, Y. Matsuzaki, S. Ceryak and H. Fromm, "Uptake Mechanism of Irinotecan (CPT-11) and Its Metabolite (SN-38) by Hamster Intestinal Cells," Gastroenterology, Vol. 114, Supplement 1, 1998, p. A626. doi:10.1016/S0016-5085(98)82560-2

[27] X. Y. Chu, Y. Kato, K. Niinuma, K. I. Sudo, H. Hakusui and Y. Sugiyama, "Multispecific Organic Anion Transporter Is Responsible for the Biliary Excretion of the Camptothecin Derivative Irinotecan and Its Metabolites in Rats," Journal of Pharmacology and Experimental Therapeutic, Vol. 281, No. 1, 1997, pp. 304-314.

[28] K. Akimoto, A. Kawai and K. Ohya, "Kinetic Studies of the Hydrolysis and Lactonization of Camptothecin and Its Derivatives, CPT-11 and SN-38, in Aqueous Solution," Chemical and Pharmaceutical Bulletin (Tokyo), Vol. 42, No. 10, 1994, pp. 2135-2138. doi:10.1248/cpb.42.2135

[29] H. Eagle, "Buffer Combinations for Mammalian Cell Culture," Science, Vol. 174, No. 4008, 1971, pp. 500-503. doi:10.1126/science.174.4008.500

[30] F. Denizot and R. Lang, "Rapid Colorimetric Assay for Cell Growth and Survival. Modifications to the Tetra- zolium Dye Procedure Giving Improved Sensitivity and Reliability," Journal of Immunological Methods, Vol. 89, No. 2, 1986, pp. 271-277. doi:10.1016/0022-1759(86)90368-6

[31] P. Rougier, R. Bugat, J. Y. Douillard, S. Culine, E. Suc, P. Brunet, Y. Becouarn, M. Ychou, M. Marty, J. M. Extra, J. Bonneterre, A. Adenis, J. F. Seitz, G. Ganem, M. Namer, T. Conroy, S. Negrier, Y. Merrouche, F. Burki, M. Mousseau, P. Herait and M. Mahjoubi, "Phase II Study of Irinotecan in the Treatment of Advanced Colorectal Cancer in Chemotherapy-Naive Patients and Patients Pretreated with Fluorouracil-Based Chemotherapy," Journal of Clinical Oncology, Vol. 15, No. 1, 1997, pp. 251-260.

[32] J. L. Flowers, R. M. Hoffman, T. A. Driscoll, M. E. Wall, M. C. Wani, G. Manikumar, H. S. Friedman, M. Dewhirst, O. M. Colvin and D. J. Adams, "The Activity of Camptothecin Analogues Is Enhanced in Histocultures of $\mathrm{Hu}$ man Tumors and Human Tumor Xenografts by Modulation of Extracellular $\mathrm{pH}$," Cancer Chemotherapy and Pharmacology, Vol. 52, No. 3, 2003, pp. 253-261. doi:10.1007/s00280-003-0635-7

[33] L. P. Rivory, E. Chatelut, P. Canal, A. Mathieu-Boue and J. Robert, "Kinetics of the in Vivo Interconversion of the Carboxylate and Lactone Forms of Irinotecan (CPT-11) and of Its Metabolite SN-38 in Patients," Cancer Research, Vol. 54, No. 24, 1994, pp. 6330-6333.

[34] V. Palissot, R. Belhoussine, Y. Carpentier, S. Sebille, H. Morjani, M. Manfait and J. Dufer, "Resistance to Apoptosis Induced by Topoisomerase I Inhibitors in MultidrugResistant HL60 Leukemic Cells," Biochemical and Biophysical Research Communications, Vol. 245, No. 3, 
1998, pp. 918-922. doi:10.1006/bbrc.1998.8550

[35] Y. Kawato, M. Sekiguchi, K. Akahane, Y. Tsutomi, Y. Hirota, H. Kuga, W. Suzuki, H. Hakusui and K. Sato, "Inhibitory Activity of Camptothecin Derivatives against Acetylcholinesterase in Dogs and Their Binding Activity to Acetylcholine Receptors in Rats," Journal of Phar- macy and Pharmacology, Vol. 45, No. 5, 1993, pp. 444448. doi:10.1111/j.2042-7158.1993.tb05573.x

[36] A. Gabr, A. Kuin, M. Aalders, H. El-Gawly and L. A. Smets, "Cellular Pharmacokinetics and Cytotoxicity of Camptothecin and Topotecan at Normal and Acidic pH," Cancer Research, Vol. 57, No. 21, 1997, pp. 4811-4816. 